\title{
Synthesis, Spectral Characterization and Antimicrobial Studies of Co(II) Complexes with Tetradentate Schiff bases Derived from Ortho- Phthalaldehyde
}

\author{
V. Sreenivas ${ }^{1}$, G. Srikanth ${ }^{1}$, Ch. Vinutha ${ }^{1}$, M. Shailaja ${ }^{1}$, P. Muralidhar Reddy
Ravinder ${ }^{{ }^{*}}$ \\ *E-mail address: ravichemku@rediffmail.com
}

\begin{abstract}
A series of cobalt (II) complexes have been synthesized with Schiff bases derived from ortho-phthalaldehyde and various amines in aqueous methanol solution. The newly synthesized Schiff bases and their Co (II) complexes have been characterized by elemental analysis, magnetic susceptibility, thermal, conductance measurements, mass, IR, electronic, ${ }^{1} \mathrm{H},{ }^{13} \mathrm{C}$-NMR spectral techniques. These ligands act as tetradentate species and coordinate to the metal center through the different potential donor atoms such as $\mathrm{N}, \mathrm{O}$ and $\mathrm{S}$. The probable octahedral structures have been assigned to these complexes. All the synthesized Schiff base ligands and Co(II) metal complexes have also been screened for their antimicrobial activities and metal complexes found to be more active than respective Schiff-base ligands.
\end{abstract}

Keywords: Ortho-phthalaldehyde; Schiff-bases; Co(II) complexes; spectral studies; antimicrobial activity.

\section{Council for Innovative Research}

Peer Review Research Publishing System

Journal: Journal of Advances in Chemistry

Vol. 9, No. 1

editorjaconline@gmail.com

www.jac.cirworld.com, member.cirworld.com 


\section{INTRODUCTION}

Schiff bases have been significant as chelating ligands in the area of coordination chemistry and their metal complexes continue to be of great interest even after over a hundred years of study [1-7]. Metal complexes make these compounds effective as specific catalysts towards oxidation [8,9], reduction [10,11], hydrolysis [12], biological activity $[13,14,15]$ and other transformations of organic and inorganic chemistry. In this regard, the synthesis of hetero-dentate $\mathrm{N}, \mathrm{O}$ and $\mathrm{S}$ donor atoms containing Schiff-bases and their metal complexes has been receiving considerable attention in recent years. Hetero-dentate Schiff bases can be designed by combining carbonyls with amino acids, hydrazines and substituted aromatic and aliphatic amines. A variety of tetra and hexadentate Schiff bases composed of $\mathrm{N}, \mathrm{O}$ and $\mathrm{S}$ donor atoms and their metal complexes have been reported in literature [16,17]. There are several reaction pathways to synthesize Schiff bases. The most common is a condensation reaction of amine and aldehyde or ketone under refluxing conditions. We have long been working on the usage of Ortho-Phthalaldehyde (OPA) as a versatile aldehyde synthone to condense with different substituted amino acids $[18,19]$ and amines in designing a new class of heterodentate Schiff-base ligands including macrocycles[20,21]. We have also been working on the catalytic, analytical and biological applications of these compounds $[22,23,24]$. In the present investigation, we report the synthesis of new tetra N, O and S donor Schiffbases and their Co (II) complexes, structural characterization and antimicrobial studies. The synthesized orthophthalaldehyde based Schiff bases are benzene-1,2-diylbis[(E)methylylidene(E)azanylylidenebenzene-2,1-diyl]dimethanol [L1], 2,2'-\{benzene-1,2 diylbis $\quad[(E) \quad$ methylylidene(E)azanylylidene]\}dibenzenethiol[L2],N',N"-[benzene-1,2diyldi(E)methylylidene]bis(2-aminobenzohydrazide) [L3], 3-[(E)-(2-\{(Z)-[(3-aminopropyl)imino]methyl\}benzylidene) amino]propan-1-amine[L4], 2-[(E)-\{2-[(1-hydroxy-2-methylpropan-2-yl) carbonoimidoyl] benzylidene\}amino] -2methylpropan-1-ol [L5]

\section{EXPERIMENTAL}

\subsection{Materials}

Cobalt chloride, Ortho -Phthalaldehyde, substituted aromatic amines (2-amino benzyl alcohol, 2-amino thiophenol, 2-Amino Benzohydrazide) 1,3-diamino propane, 2-amino 2-methyl 1-propanol and other chemicals were purchased from Aldrich, USA and all other compounds are analytical grade products from Merck. The solvents were distilled and stored over molecular sieves. The purity of the compounds was checked by TLC using Merck $60 \mathrm{~F} 254$ silica gel plates

\subsection{Physical Measurements}

The percentages of carbon, hydrogen, nitrogen in Schiff bases and their Co(II) complexes were determined using a Perkin-Elmer $\mathrm{CHN}$ analyzer at $240^{\circ} \mathrm{C}$. Conductance measurements were done on $10^{-3} \mathrm{M}$ solution of compounds in dichloromethane at $25{ }^{\circ} \mathrm{C}$ using Digisun Digital conductivity meter model DL-909. The magnetic studies of complexes in solid state were carried out at room temperature on a Gouy balance calibrated with $\mathrm{Hg}$ [Co (SCN) 4 ]. The TG-DTA thermo grams of the complexes were recorded on the Mettler Toledo star system. UV-Visible spectra were recorded with Shimadzu UV-160A, a UV-Visible double beam spectrophotometer with matched quartz cells of path length $1 \mathrm{~cm}$. The IR spectra were recorded in $\mathrm{KBr}$ pellets on a Perkin-Elmer 283 spectrophotometer. Brucker WH $300(200 \mathrm{MHz})$ and Brucker WH $270(67.93 \mathrm{MHz})$ spectrometers were used for ${ }^{1} \mathrm{H}$ NMR and ${ }^{13} \mathrm{C}$ NMR measurements. ESI and FAB MS were used to obtain mass spectra. Hot air oven (Instrument and equipment Pvt. Ltd., Mumbai), incubator (Instrument and equipment Pvt. Ltd., Mumbai), laminar air flow unit (Claslaminar technologies Pvt. Ltd. Secunderabad), autoclave (Medica instrument Mfg.Co. Mumbai) were used in the antimicrobial investigations. The antimicrobial activity of the compounds was determined by the cup plate method and the minimum inhibitory concentration by liquid dilution method at Department of microbiology, Kakatiya University, Warangal.

\subsection{Synthesis of Ligands}

All the Schiff base ligands $\left(L_{1}, L_{2}, L_{3}, L_{4}\right.$ and $\left.L_{5}\right)$ were prepared by the addition of $25 \mathrm{ml}$ aqueous methanolic solution of Orthophthalaldehyde $(2.68 \mathrm{~g}, 0.02 \mathrm{~mol}$.) to the $25 \mathrm{ml}$ of aqueous methanolic solution of aromatic amine $(0.04$ mol viz. $4.92 \mathrm{~g}$ of 2-amino benzyl alcohol $\left(\mathrm{L}_{1}\right), 5 \mathrm{~g}$ of 2-amino thiophenol $\left(\mathrm{L}_{2}\right), 6.04 \mathrm{~g}$ of 2-Amino Benzohydrazide $\left(\mathrm{L}_{3}\right), 2.96$ $\mathrm{g}$ of 1,3 diamino propane ( $\mathrm{L}_{4}$.) $3.56 \mathrm{~g}$ of 2-amino 2-methyl 1-propanol) $\left(\mathrm{L}_{5}\right)$. This reaction mixture was refluxed for $90-180$ min. After cooling, crystalline precipitate was formed. It was filtered by suction filtration, washed with cold methanol and diethyl ether in small portions, dried in a vacuum and recrystallized from ethanol.

\subsection{Synthesis of Schiff base Co(II) Complexes}

The five ligands and metal salt $\mathrm{CoCl}_{2} 6 \mathrm{H}_{2} \mathrm{O}$ were used as starting materials. Because of similar structure and properties of all the Schiff base ligands a general method of preparation of the complexes was used. $0.714 \mathrm{~g}(0.003 \mathrm{~mol}$.) of $\mathrm{CoCl}_{2} 6 \mathrm{H}_{2} \mathrm{O}$ was dissolved in $20 \mathrm{ml}$ of methanol. To this solution, $20 \mathrm{ml}$ of ligand solution $\left(0.003 \mathrm{~mol}\right.$., viz. $1.032 \mathrm{~g}$ of $\mathrm{L}_{1}$, $1.045 \mathrm{~g}$ of $L_{2}, 1.201 \mathrm{~g}$ of $L_{3}, 0.739 \mathrm{~g}$ of $L_{4}, 0.828 \mathrm{~g}$ of $L_{5}$, in methanol) was added. The reaction mixture was taken in a 100 $\mathrm{ml}$ round bottom flask and stirred magnetically. The volume of the solution was decreased to $5 \mathrm{ml}$ under reduced pressure and then a few $\mathrm{ml}$ of diethyl ether was added to instigate the crystallization. The product formed was separated by suction filtration, washed with diethyl ether and vacuum dried to get a crystalline compound. This compound was recrystallized by using dichloromethane and diethyl ether solvent mixture. 


\subsection{Antimicrobial Activity}

Organisms like Escherichia coli, Klebsiella pneumonia, Basillus subtilis, Staphylococcus aureus, were used for the In vitro antibacterial and Aspergillus flavus, Fusarium oxysporium were for the antifungal activity studies of al synthesized ligands and their Co(II) complexes. Antibiotics such as Streptomycin, Rifampicin, and Itrazole were used as the standards for the antibacterial and the antifungal activity studies. Antimicrobial testing was done by cup plate method [25].A standard microorganism media viz. nutrient agar medium and nutrient broth medium (supplied by Hi-media, Mumbai) used for the bacterial and Saborauds agar medium (Hi- media, Mumbai) for the fungal studies. A $1000 \mu \mathrm{g} / \mathrm{ml}$ testing sample solution (Schiff bases and their Co(II) metal complexes) was prepared by dissolving $10 \mathrm{mg}$ of it in $10 \mathrm{ml}$ of a suitable solvent (initially water, methanol and DMSO) [26]. Solutions with different concentrations such as 100, 50, 20, $15,10,5,2,1 \mu \mathrm{g} / \mathrm{ml}$ were prepared from the sample solution by further dilution. Sterile Petri dishes were taken to which 27 $\mathrm{ml}$ of molten agar is added and allowed to solidify and set for $1 \mathrm{hr}$. Then $50 \mathrm{ml}$ of the $24 \mathrm{hrs}$ culture of a test organism was taken on to the agar plate and spread evenly with the sterile cotton swab. $6 \mathrm{~mm}$ wide bores were made on the agar using a borer. The solutions of the Schiff bases or Schiff bases Co(II) complexes were added into each of the bores in appropriately using a sterile tip with micropipette and labeled as Petri dishes. Similar plates were also prepared for Standard antibiotics. These dishes were then incubated aerobically at the $37 \mathrm{OC}$ for 24 hours with bacterial cultures and fungal cultures at the $25 \mathrm{OC}$ for 48h [27]. The zones of inhibition of growth were found compared with standard antibiotics. The activities of compounds were interpreted as active, inactive. The minimum inhibitory concentration required was also found when a series of dilutions were tested.

\section{RESULTS AND DISCUSSION}

In the present investigations, five new Schiff base ligands were synthesized by condensation of Orthophthalaldehyde with different amines and amino benzohydrazides in basic medium (Scheme1). By using these Schiff bases five new hexa coordinated Schiff base Co (II) complexes were synthesized by treating $\mathrm{CoCl}_{2} \cdot 6 \mathrm{H}_{2} \mathrm{O}$, with two $\mathrm{N}_{2} \mathrm{O}_{2}$, two $\mathrm{N}_{2} \mathrm{~S}_{4}$ and one $\mathrm{N}_{4}$ donor Schiff base ligands separately and all the complexes are stable in air and soluble in ethanol. The percentages of carbon, hydrogen and nitrogen were determined experimentally using $\mathrm{CHN}$ analyzer. The physical and analytical data (Table 1) for the newly synthesized compounds is in good agreement with the proposed molecular formulae.<smiles>O=Cc1ccccc1C=O</smiles>

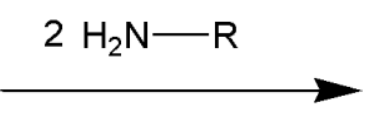
Base OPA $\mathrm{R}=$<smiles>Cc1ccccc1CO</smiles>

$\mathrm{L}_{1}$<smiles>Cc1ccccc1S</smiles>

$\mathrm{L}_{2}$<smiles>CNC(=O)c1ccccc1N</smiles>

$\mathrm{L}_{3}$<smiles>[R]N=Cc1ccccc1C=N[R6]</smiles>

Scheme 1: preparation methods of Schiff base compounds containing azomethaine group L1-L5 
Table 1. Physical and analytical data of Schiff bases and their Co (II) complexes

\begin{tabular}{|c|c|c|c|c|c|c|c|}
\hline \multirow{2}{*}{$\begin{array}{c}\text { Compound } \\
\text { (Molecular formula) }\end{array}$} & \multirow{2}{*}{$\begin{array}{c}\text { Mol. } \\
\text { Wt }\end{array}$} & \multirow{2}{*}{$\begin{array}{c}\text { React. } \\
\text { time } \\
\text { (min) }\end{array}$} & \multirow[t]{2}{*}{ Color (\% Yield) } & \multicolumn{4}{|c|}{ Elemental Analysis (\%) found (calculated) } \\
\hline & & & & C & $\mathrm{H}$ & $\mathrm{N}$ & Co \\
\hline $\mathrm{L}_{1}\left(\mathrm{C}_{22} \mathrm{H}_{20} \mathrm{~N}_{2} \mathrm{O}_{2}\right)$ & 344 & 120 & Light Yellow(72) & $76.69(76.72)$ & $5.83(5.85)$ & $8.19(8.13)$ & \\
\hline $\mathrm{L}_{2}\left(\mathrm{C}_{20} \mathrm{H}_{16} \mathrm{~N}_{2} \mathrm{~S}_{2}\right)$ & 348 & 95 & Coffee $(80)$ & $68.82(68.93)$ & $4.67(4.63)$ & $8.21(8.04)$ & \\
\hline $\mathrm{L}_{3}\left(\mathrm{C}_{22} \mathrm{H}_{20} \mathrm{~N}_{6} \mathrm{O}_{2}\right)$ & 401 & 150 & yellow(79) & $65.81(65.99)$ & $5.14(5.03)$ & $20.89(20.99)$ & \\
\hline $\mathrm{L}_{4}\left(\mathrm{C}_{14} \mathrm{H}_{22} \mathrm{~N}_{4}\right)$ & 246 & 130 & Light Yellow(75) & $68.34(68.26)$ & $9.06(9.00)$ & $22.80(22.74)$ & \\
\hline $\mathrm{L}_{5}\left(\mathrm{C}_{16} \mathrm{H}_{24} \mathrm{~N}_{2} \mathrm{O}_{2}\right)$ & 276 & 145 & White(81) & $69.55(69.53)$ & $8.63(8.75)$ & $10.22(10.14)$ & \\
\hline $\begin{array}{l}{\left[\mathrm{CoL}_{1}\left(\mathrm{H}_{2} \mathrm{O}\right)_{2}\right]} \\
\left(\mathrm{C}_{22} \mathrm{H}_{22} \mathrm{CoN}_{2} \mathrm{O}_{4}\right)\end{array}$ & 437 & 172 & $\operatorname{Pink}(76)$ & $60.46(60.42)$ & $5.09(5.07)$ & $6.38(6.41)$ & $13.45(13.47)$ \\
\hline $\begin{array}{l}{\left[\mathrm{CoL}_{2}\left(\mathrm{H}_{2} \mathrm{O}\right)_{2}\right]} \\
\left(\mathrm{C}_{20} \mathrm{H}_{18} \mathrm{CoN}_{2} \mathrm{O}_{2} \mathrm{~S}_{2}\right)\end{array}$ & 441 & 160 & Brown(73) & $54.39(54.42)$ & $4.07(4.11)$ & $6.39(6.35)$ & 13.31(13.35) \\
\hline $\begin{array}{l}{\left[\mathrm{CoL}_{3}(\mathrm{Cl})_{2}\right]} \\
\left.\mathrm{C}_{22} \mathrm{H}_{20} \mathrm{Cl}_{2} \mathrm{CoN}_{6} \mathrm{O}_{2}\right)\end{array}$ & 530 & 90 & Dark Green(76) & $50.63(50.66)$ & $4.29(4.25)$ & $15.40(15.41)$ & $10.82(10.81)$ \\
\hline $\begin{array}{l}{\left[\mathrm{CoL}_{4}(\mathrm{Cl})_{2}\right]} \\
\left(\mathrm{C}_{14} \mathrm{H}_{22} \mathrm{Cl}_{2} \mathrm{CoN}_{4}\right)\end{array}$ & 376 & 100 & Violet(80) & $44.72(44.70)$ & $5.85(5.89)$ & $14.92(14.89)$ & 15.65(15.67) \\
\hline $\begin{array}{l}{\left[\mathrm{CoL}_{5}\left(\mathrm{H}_{2} \mathrm{O}\right)_{2}\right]} \\
\left(\mathrm{C}_{16} \mathrm{H}_{26} \mathrm{CoN}_{2} \mathrm{O}_{4}\right)\end{array}$ & 369 & 120 & Light Pink(79) & $53.28(53.26)$ & $7.39(7.36)$ & $7.29(7.31)$ & $15.35(15.37)$ \\
\hline
\end{tabular}

\subsection{Infrared spectral analysis}

The infrared spectra of the free ligands were compared with those of the new Schiff base Co(II) complexes to access the coordination of ligand to $\mathrm{Co}(\mathrm{II})$ ion. In the IR spectra of the Schiff base ligands, a medium intensity $\mathrm{U}_{\text {the }} \mathrm{C}=\mathrm{N}$ band was observed in the range of $1665-1639 \mathrm{~cm}^{-1}$ [28]. This shift towards lower side about $45-60 \mathrm{~cm}^{-1}$ in case of Schiff base Co (II) complexes and supports the coordination of nitrogen of $\mathrm{C}=\mathrm{N}$ group [29]. This fact that the ligands coordinate through nitrogen atoms is further supported by the appearance of a medium intensity band in the region of $528-556 \mathrm{~cm}^{-1}$ assignable to UM-N vibration. However, the IR spectra of Schiff base ligands $L_{3}$ and $L_{4}$ shown a broad in the range of 3448 $3444 \mathrm{~cm}^{-1}$ corresponding to UNH vibrations. This band was shifted towards lower side about $99-108 \mathrm{~cm}^{-1}$ in case of Schiff base Co (II) compounds. This supports the fact that the ligands coordinate to the metal ion through the a nitrogen of $\mathrm{C}=\mathrm{N}$ group and nitrogen of the $\mathrm{NH}$ group in these Schiff base Co (II) complexes [30]. In ligand 2 weak band is observed in the range of $2550 \mathrm{~cm}^{-1}$ due to usH be suggestive of thiole form. After the coordination of this phenolic sulphar by deprotonation is further supported by the disappearance of $\mathrm{USH}_{\mathrm{SH}}$ in the range of $2550 \mathrm{~cm}^{-1}$ and appeared at $427 \mathrm{~cm}^{-1}$ in corresponding Co(II) complexes. In case of Schiff base ligands $L_{1}$ and $L_{5}$ broad band were observed in the range of $3435 \mathrm{~cm}^{-1}$ and 3448 $\mathrm{cm}^{-1}$. After the coordination of this benzylic oxygen and methylenic oxygen by deprotonation were further supported by the disappearance of $\mathrm{VOH}$ in the range of $3435 \mathrm{~cm}^{-1}$ and $3448 \mathrm{~cm}^{-1}$ and appeared at $439 \mathrm{~cm}^{-1}$ and $442 \mathrm{~cm}^{-1}$ in corresponding Co(II) complexes. The characteristic band in Schiff base ligand $L_{3}$ due to the $v_{C}=0$ is observed at 1687. But in the respective Schiff base $\mathrm{Co}$ (II) compound was remain almost unaltered. All the characteristic bands due to the aromatic rings [31] were also present in the expected regions in all the Schiff base Co(II) compounds (Table-2).

\subsection{NMR Spectral Analysis}

${ }^{1} \mathrm{H}$ NMR spectral comparison between Schiff bases and their $\mathrm{Co}(\mathrm{II})$ complexes was made to confirm the binding nature of Schiff bases to $\mathrm{Co}(\mathrm{II})$ ions. In all the ligands signals $\mathrm{CH}=\mathrm{N}$ protons were appeared in the range of 8.1-8.4 $\delta[32]$. However the coordination of nitrogen atom of the $\mathrm{CH}=\mathrm{N}$ group to $\mathrm{Co}$ (II) ion is confirmed by the appearance of signals in the range of 8.26-8.52 $\delta$. In the spectra of Schiff base ligand 1 signal at $2.8 \delta$ was appeared due to benzylic OH proton and Schiff base ligand 5 signal was appeared at $2.5 \delta[33]$ corresponding to $\mathrm{OH}$ protons however these signals are disappeared in the $\mathrm{Co}$ (II) complex suggesting that the $\mathrm{OH}$ protons are deprotonated and the oxygen atoms coordinated with metal ions. In Schiff base 2 due to aromatic SH proton the signal was appeared at down in the field region at $3.2 \delta$, however this signal was disappeared in the $\mathrm{Co}(\mathrm{II})$ complex suggesting that the $\mathrm{SH}$ protons are deprotonated and the sulphar atom 
coordinated with metal ions. And in the case of Schiff base ligand 3 the signal due to aromatic $\mathrm{NH}_{2}$ was appeared at $4.2 \delta$ and in the case of Schiff base ligand 4 the signal due to aliphatic $\mathrm{NH}_{2}$ was appeared at $2.2 \delta$. But these signals were disappeared in the respective $\mathrm{Co}$ (II) complexes indicating the participation of nitrogen in the coordination to the Co(II) ion by deprotonation. There is no appreciable change in the peak positions corresponding to aromatic protons [29]. ${ }^{13} \mathrm{C}$ NMR spectra of free Schiff base ligands were compared with the corresponding Schiff base ligand Co(II) compounds and the chemical shifts in the spectra revealed a consistent pattern. The spectra of all the ligands contain signals in the range of 160.1-160.9 [34] due to the presence of carbon which is doubly bonded to nitrogen. In the spectra of Schiff base Co(II) compounds, a down field shift in peak position is observed in the range of 160.9-161.2 $\delta$ [35]. This evidence confirms that the ligands coordinate through nitrogen atoms. Appreciable changes in peak positions were not observed with respect to aryl carbons and carbons adjacent to nitrogen/sulphur/oxygen atom [34]. The individual ${ }^{1} \mathrm{H}$ peak positions of selected protons and peak positions of selected carbon atoms of all the Schiff base Co(II) compounds are given in Table-3.

Table. 2 : IR (in $\mathrm{cm}-1$ ) spectral data of ligands and their Co(II) complexes

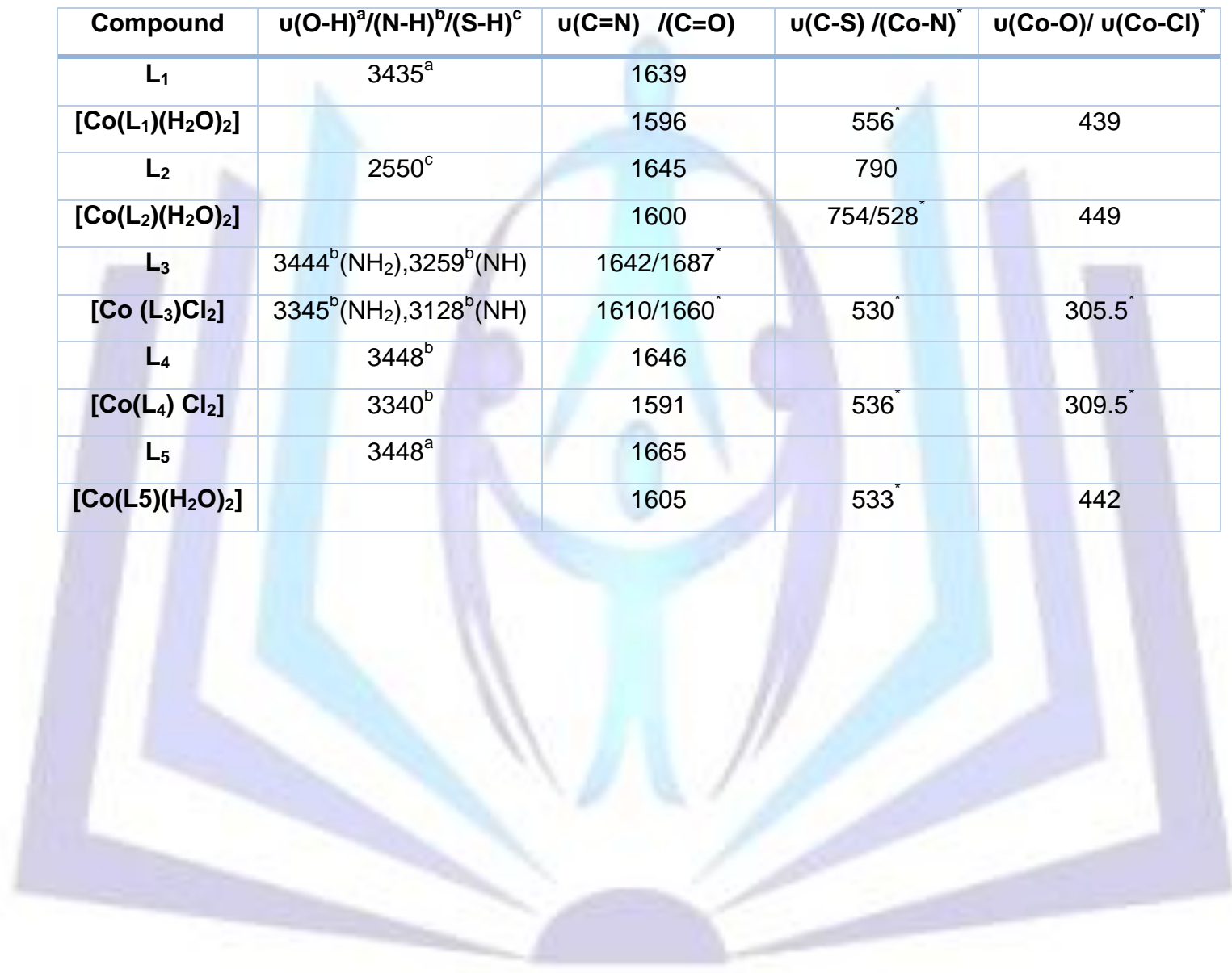


Table 3. ${ }^{1} \mathrm{H}$ and ${ }^{13} \mathrm{C}$ NMR spectral data of Schiff base ligands and their $\mathrm{Co}(\mathrm{II})$ complexes Compound ${ }^{1} \mathrm{H}$ NMR peak position ( $\left.\delta \mathrm{ppm}\right)$ 13C NMR peak position ( $\delta \mathrm{ppm})$

\begin{tabular}{|c|c|c|}
\hline $\mathrm{L}_{1}$ & $\begin{array}{l}8.3(2 \mathrm{H}, \mathrm{s}, \mathrm{CH}=\mathrm{N}), 6.8-7.4(12 \mathrm{H}, \mathrm{m}, \mathrm{Ar}-\mathrm{H}), 4.65 \\
\left(4 \mathrm{H}, \mathrm{s}, \mathrm{CH}_{2}-\mathrm{O}\right), 2.8(2 \mathrm{H}, \mathrm{s}, \mathrm{OH})\end{array}$ & $\begin{array}{l}59.5(2 \mathrm{C}, \mathrm{O}-\mathrm{C}) 122.5,127.5,128.5,129.0,129.3 \\
131.2,132.7,134.1,149.3(18 \mathrm{C}, \mathrm{Ar}-\mathrm{C}) 160.1(2 \mathrm{C} \\
\mathrm{CH}=\mathrm{N})\end{array}$ \\
\hline$\left[\mathrm{Co}\left(\mathrm{L}_{1}\right)\left(\mathrm{H}_{2} \mathrm{O}\right)_{2}\right]$ & $\begin{array}{l}\text { 8. } 47(2 \mathrm{H}, \mathrm{s}, \mathrm{CH}=\mathrm{N}), 6.4-7.5(12 \mathrm{H}, \mathrm{m}, \mathrm{Ar}-\mathrm{H}) \text {, } \\
4.68\left(4 \mathrm{H}, \mathrm{s},-\mathrm{CH}_{2}\right)\end{array}$ & $\begin{array}{l}\text { 122.4, 127.5, 129.7, 130.1, 131.4, 134.3(18C, Ar- } \\
\mathrm{C}), 161.2(2 \mathrm{C}, \mathrm{CH}=\mathrm{N}), 13\left(2 \mathrm{C}, \mathrm{CH}_{2}\right)\end{array}$ \\
\hline $\mathbf{L}_{2}$ & $\begin{array}{l}8.39(2 \mathrm{H}, \mathrm{s}, \mathrm{CH}=\mathrm{N}), 6.9-7.8(12 \mathrm{H}, \mathrm{m}, \mathrm{Ar}-\mathrm{H}), 3.2 \\
(2 \mathrm{H}, \mathrm{s}, \mathrm{SH})\end{array}$ & $\begin{array}{l}\text { 122.6, 126.0, 126.9, 127.6, 129.3, 130.7, } 131.2 \\
134.1,158.2(18 \mathrm{C}, \mathrm{Ar}-\mathrm{C}) 160.1(2 \mathrm{C}, \mathrm{CH}=\mathrm{N})\end{array}$ \\
\hline$\left[\mathrm{Co}\left(\mathrm{L}_{2}\right) \mathrm{H}_{2} \mathrm{O}\right]$ & $8.43(2 \mathrm{H}, \mathrm{s}, \mathrm{CH}=\mathrm{N}), 7.1-8.0(12 \mathrm{H}, \mathrm{m}, \mathrm{Ar}-\mathrm{H})$ & $\begin{array}{l}\text { 121.9, 127.5, 129.8, 130.1, 131.4, 134.8, } 153.2 \\
(18 \mathrm{C}, \mathrm{Ar}-\mathrm{C}), 161.1(2 \mathrm{C}, \mathrm{CH}=\mathrm{N})\end{array}$ \\
\hline $\mathrm{L}_{3}$ & $\begin{array}{l}8.1(2 \mathrm{H}, \mathrm{s}, \mathrm{CH}=\mathrm{N}), 8.0(2 \mathrm{H}, \mathrm{s}, \mathrm{NH}-\mathrm{CO}), 6.6- \\
7.9(12 \mathrm{H}, \mathrm{m}, \mathrm{Ar}-\mathrm{H}), 4.2\left(4 \mathrm{H}, \mathrm{s}, \mathrm{Ar}-\mathrm{NH}_{2}\right)\end{array}$ & $\begin{array}{l}\text { 116.4, 118.0, 118.9, 128.3, 129.3, 131.2, } 133.0 \\
\text { 134.1, 148.4, (18C, Ar-C), } 160.1(2 \mathrm{C}, \mathrm{CH}=\mathrm{N}) 163.0 \\
(2 \mathrm{C}, \mathrm{C}=\mathrm{O})\end{array}$ \\
\hline [Co $\left.\left(\mathrm{L}_{3}\right) \mathrm{Cl}_{2}\right]$ & $\begin{array}{l}8.26(2 \mathrm{H}, \mathrm{s}, \mathrm{CH}=\mathrm{N}), 8.0(2 \mathrm{H}, \mathrm{s}, \mathrm{NH}-\mathrm{CO}), 6.2- \\
7.9(12 \mathrm{H}, \mathrm{m}, \mathrm{Ar}-\mathrm{H}), 4.8\left(4 \mathrm{H}, \mathrm{s}, \mathrm{Ar}-\mathrm{NH}_{2}\right)\end{array}$ & $\begin{array}{l}\text { 116.4, 119.1, 128.4, 129.4, 131.5, 143.4, } 148.7 \\
(18 \mathrm{C}, \mathrm{Ar}-\mathrm{C}), 143.8(2 \mathrm{C}, \mathrm{CH}=\mathrm{N}), 163.5(2 \mathrm{C}, \mathrm{C}=\mathrm{O})\end{array}$ \\
\hline $\mathbf{L}_{4}$ & $\begin{array}{l}8.2(2 \mathrm{H}, \mathrm{s}, \mathrm{CH}=\mathrm{N}), 7.2-7.9,(4 \mathrm{H}, \mathrm{m}, \mathrm{Ar}-\mathrm{H}), 2.2 \\
\left(4 \mathrm{H}, \mathrm{s}, \mathrm{NH}_{2}\right), 3.55\left(4 \mathrm{H}, \mathrm{t}, \mathrm{CH}_{2}-\mathrm{N}=\right), 2.65(4 \mathrm{H}, \mathrm{t}, \\
\left.\mathrm{CH}_{2}-\mathrm{NH}_{2}\right) 1.91\left(4 \mathrm{H}, \mathrm{m}, \mathrm{C}-\mathrm{CH}_{2}-\mathrm{C}\right)\end{array}$ & $\begin{array}{l}34.3,39.7,59.0\left(6 \mathrm{C}, \mathrm{CH}_{2}-\mathrm{C}\right) 129.3,131.2,140.2 \\
(6 \mathrm{C}, \mathrm{Ar}-\mathrm{C}), 160.9(2 \mathrm{C}, \mathrm{CH}=\mathrm{N})\end{array}$ \\
\hline$\left[\mathrm{Co}\left(\mathrm{L}_{4}\right) \mathrm{Cl}_{2}\right]$ & $\begin{array}{l}8.36(2 \mathrm{H}, \mathrm{s}, \mathrm{CH}=\mathrm{N}), 7.3-7.9,(4 \mathrm{H}, \mathrm{m}, \mathrm{Ar}-\mathrm{H}), 2.45 \\
\left(4 \mathrm{H}, \mathrm{s}, \mathrm{NH}_{2}\right), 3.56\left(4 \mathrm{H}, \mathrm{t}, \mathrm{CH}_{2}-\mathrm{N}=\right), 2.68(4 \mathrm{H}, \mathrm{t} \\
\left.\mathrm{CH}_{2}-\mathrm{NH}_{2}\right) 1.92\left(4 \mathrm{H}, \mathrm{m}, \mathrm{C}-\mathrm{CH}_{2}-\mathrm{C}\right)\end{array}$ & $\begin{array}{l}\text { 129.7, 131.4, } 140.5(6 \mathrm{C}, \mathrm{Ar}-\mathrm{C}), 161.1(2 \mathrm{C}, \mathrm{CH}=\mathrm{N}) \\
34.5,39.1,59.5\left(6 \mathrm{C}, \mathrm{CH}_{2}\right)\end{array}$ \\
\hline $\mathbf{L}_{5}$ & $\begin{array}{l}8.4(2 \mathrm{H}, \mathrm{s}, \mathrm{CH}=\mathrm{N}), 7.5-7.8(4 \mathrm{H}, \mathrm{m}, \mathrm{Ar}-\mathrm{H}), 3.8 \\
\left(4 \mathrm{H}, \mathrm{s}, \mathrm{O}-\mathrm{CH}_{2}\right), 2.5(2 \mathrm{H}, \mathrm{s}, \mathrm{OH}), 1.4(12 \mathrm{H}, \mathrm{s} \\
\left.\mathrm{CH}_{3}\right)\end{array}$ & $\begin{array}{l}26.2,\left(4 \mathrm{C}, \mathrm{CH}_{3}-\mathrm{C}\right), 55.5\left(2 \mathrm{C}, 3^{0} \mathrm{C}\right), 72.0(2 \mathrm{C}, \mathrm{C}-\mathrm{O}) \\
129.3,131.2,140.2(6 \mathrm{C}, \mathrm{Ar}-\mathrm{C}), 160.9(2 \mathrm{C}, \mathrm{CH}=\mathrm{N})\end{array}$ \\
\hline$\left[\mathrm{Co}(\mathrm{L} 5)\left(\mathrm{H}_{2} \mathrm{O}\right)_{2}\right]$ & $\begin{array}{l}8.52(2 \mathrm{H}, \mathrm{s}, \mathrm{CH}=\mathrm{N}), 7.5-7.8(4 \mathrm{H}, \mathrm{m}, \mathrm{Ar}-\mathrm{H}), 3.95 \\
\left(4 \mathrm{H}, \mathrm{s},-\mathrm{CH}_{2}\right), 1.3\left(12 \mathrm{H}, \mathrm{s}, \mathrm{CH}_{3}\right) .\end{array}$ & $\begin{array}{l}\text { 129.4, } 131.4,140.3(6 \mathrm{C}, \mathrm{Ar}-\mathrm{C}), 160.4(2 \mathrm{C}, \mathrm{CH}=\mathrm{N}) \\
27.8,32.9\left(4 \mathrm{C}, \mathrm{CH}_{3}\right), 25(2 \mathrm{C}, \mathrm{C}-\mathrm{O})\end{array}$ \\
\hline
\end{tabular}

\subsection{Mass Spectral Analysis}

The anticipated molecular formula of Co(II) complexes was confirmed by the mass spectral investigation by comparing their molecular formula weights with $\mathrm{m} / \mathrm{z}$ values. The mass spectra of ligands viz. L1, L3, and L4 has shown molecular ion peaks $(\mathrm{M}++\mathrm{Na})$ at $367.4(30 \%), 424.6(15 \%), 269(27 \%)$, L5 shown molecular ion peak $(\mathrm{M}++1)$ at 277 (25\%), and L2 shown molecular ion peak at the $\mathrm{M}+$ peak at $348(70 \%)$ respectively. This data is in good agreement with the respective molecular formulae. The mass spectra of Schiff base Co(II) complexes viz. for complex [CoL2(H2O)2] , [CoL4(Cl)2] and [CoL5(H2O)2] shown molecular ion peak $(\mathrm{m} / \mathrm{z})$ at 441, 376 and 369. And for complex [CoL3(Cl)2]) shown peak $\left(\mathrm{M}_{++1}\right)$ at $(\mathrm{m} / \mathrm{z}) 531$. However, for complex [CoL1 $\left.(\mathrm{H} 2 \mathrm{O}) 2\right]$ shown peak $(\mathrm{M}++\mathrm{Na})$ at $(\mathrm{m} / \mathrm{z})$ 460. These values are in good agreement with the respective weights of the Schiff base Co(II) compounds calculated on the basis proposed molecular formulae.

\subsection{Electronic Spectral Analysis}

The electronic spectra of the Schiff base Co(II) complexes were recorded at room temperature and electronic spectral data of these complexes are summarized in Table 4. These Schiff base Co(II) complexes exhibit three bands in the 9225$9606\left(U_{1}\right), 19120-19531\left(U_{2}\right)$, and $21141-22172\left(U_{3}\right) \mathrm{cm}^{-1}$ regions corresponding to ${ }^{4} \mathrm{~T}_{1 \mathrm{~g}}(\mathrm{~F}) \rightarrow{ }^{4} \mathrm{~T}_{2 \mathrm{~g}}(\mathrm{~F}),{ }^{4} \mathrm{~T} 1 \mathrm{~g}(\mathrm{~F}) \rightarrow{ }^{4} \mathrm{~A}_{2 \mathrm{~g}}(\mathrm{~F})$ and ${ }^{4} \mathrm{~T}_{1 \mathrm{~g}}(\mathrm{~F}) \rightarrow{ }^{4} \mathrm{~T}_{1 \mathrm{~g}}(\mathrm{P})$ transitions, respectively suggesting an octahedral geometry [35]. The octahedral geometry was further supported by $U_{2}$ to $U_{1}$ ratio, which was lying in the range of 1.99-2.11 [36].

\subsection{Molar Conductance, Magnetic susceptibility and Thermal studies}

The molar conductance values for all the Schiff base $\mathrm{Co}(\mathrm{II})$ complexes $\left(10^{-3} \mathrm{M}\right)$ were determined in dichloromethane [37]. These values were found to be low $\left(11.5-17.7 \mathrm{ohm}^{-1} \mathrm{~cm}^{2} \mathrm{~mol}^{-1}\right)$ indicating non-electrolytic nature. The magnetic moments of $\mathrm{Co}$ (II) complexes at room temperature are in the range of 4.68-5.01 B.M., thus confirm octahedral geometry around metal ion. The TGA and DTA studies of Schiff base Co(II) complexes with ligands $L_{1}, L_{2}$, and $L_{5}$ revealed that there are two clear cut stages in the decomposition of complexes, first one is due to the dehydration and the other one is owing to the decomposition with the loss of organic moiety. In the TGA dehydration curve, a peak corresponding to the loss of the water molecule in the temperature range of $80-120 \circ \mathrm{C}$ was observed. This temperature range indicating that the presence of lattice-held water molecules [38]. In the TGA decomposition curve, a peak in the temperature range of 228-255 $\mathrm{C}$ was observed indicative to the loss of organic moiety. Further the DTA curves which contain endothermic peaks in the temperature range $90-120 \circ \mathrm{C}$ supported the presence of water molecules in the Schiff base Co(II) complexes . In 
contrast, the thermograms of Schiff base Co(II) complexes which contains ligands $L_{2}$ and $L_{3}$ exhibited only a single decomposition curve of around 235-255 $\mathrm{C}$ corresponding to the loss of organic moiety. Organic moieties of Schiff base Co (II) complexes were decomposed, above $5600^{\circ} \mathrm{C}$, resulting in the formation of cobalt oxide. The molar conductance, magnetic susceptibility and thermal data of Schiff base Co (II) compounds are summarized in Table 4.

Table 4. Electronic, molar conductance, magnetic susceptibility and thermal data of Schiff bases and their Co (II) complexes

\begin{tabular}{|c|c|c|c|c|c|c|}
\hline $\begin{array}{l}\text { Schiff base } \\
\text { complex }\end{array}$ & Absorption maxima $\left(\mathrm{cm}^{-1}\right)$ & $\begin{array}{c}\Lambda_{\mathrm{M}}\left(\Omega^{-1}\right. \\
\mathrm{cm}^{2} \\
\left.\mathrm{~mol}^{1}\right)\end{array}$ & $\mu_{\mathrm{eff}}($ B.M.) & $\begin{array}{l}\mathbf{U}_{2} / \\
\mathbf{U}_{1}\end{array}$ & $\begin{array}{c}\text { Decompositi } \\
\text { on } \\
\text { temp }\left({ }^{\circ} \mathrm{C}\right)\end{array}$ & $\begin{array}{l}\text { Loss of water (\%) } \\
\text { Found (calculated) }\end{array}$ \\
\hline$\left[\mathrm{Co}\left(\mathrm{L}_{1}\right)\left(\mathrm{H}_{2} \mathrm{O}\right)_{2}\right]$ & $9606\left(\mathrm{u}_{1}\right), 19120\left(\mathrm{u}_{2}\right), 22123\left(\mathrm{u}_{3}\right)$ & 11.5 & 4.68 & 1.99 & 252 & $6.05(6.20)$ \\
\hline$\left[\mathrm{Co}\left(\mathrm{L}_{2}\right)\left(\mathrm{H}_{2} \mathrm{O}\right)_{2}\right]$ & $9460\left(U_{1}\right), 19193\left(U_{2}\right), 21598\left(U_{3}\right)$ & 17.7 & 4.87 & 2.02 & 241 & $6.54(6.77)$ \\
\hline$\left[\mathrm{Co}\left(\mathrm{L}_{3}\right) \mathrm{Cl}_{2}\right]$ & $9225\left(U_{1}\right), 19531\left(U_{2}\right), 21141\left(U_{3}\right)$ & 15.9 & 4.72 & 2.11 & 235 & - \\
\hline$\left[\mathrm{Co}\left(\mathrm{L}_{4}\right) \mathrm{Cl}_{2}\right]$ & $9345\left(u_{1}\right), 19305\left(u_{2}\right), 22172\left(u_{3}\right)$ & 16.1 & 4.76 & 2.06 & 255 & - \\
\hline$\left[\mathrm{Co}(\mathrm{L} 5)\left(\mathrm{H}_{2} \mathrm{O}\right)\right]$ & $9301\left(u_{1}\right), 19195\left(u_{2}\right), 21186\left(u_{3}\right)$ & 12.1 & 5.01 & 2.06 & 228 & 7.01(7.07) \\
\hline
\end{tabular}

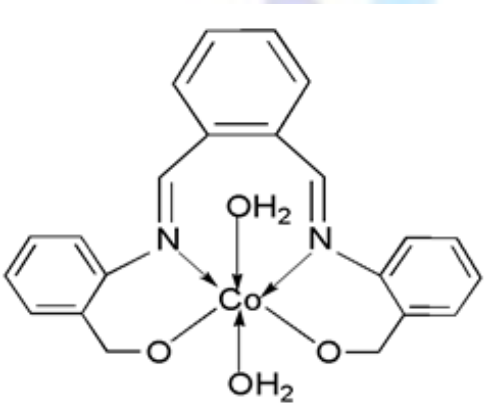

$\mathrm{Co}\left(\mathrm{L}_{1}\right)\left(\mathrm{H}_{2} \mathrm{O}\right)_{2}$<smiles></smiles>

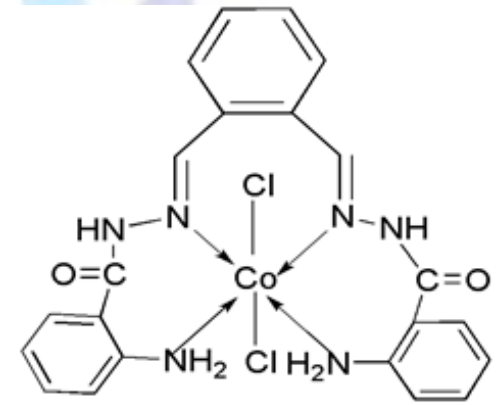

$\mathrm{Co}\left(\mathrm{L}_{3}\right) \mathrm{Cl}_{2}$

$\mathrm{Co}\left(\mathrm{L}_{2}\right)\left(\mathrm{H}_{2} \mathrm{O}\right)_{2}$

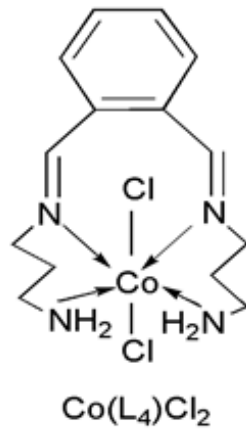

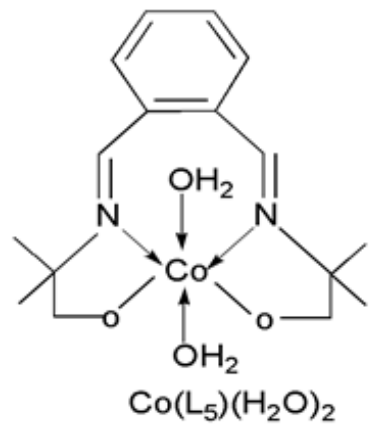

Scheme 2. Proposed structures of all Schiff base Co(II)complexes

\section{ANTIMICROBIAL ACTIVITY}

Based on the results, the Schiff base ligands showed no activity or having low to moderate activity. In contrast, the Co(II) metal complexes were found to be very active against the microorganism. The rise in the antimicrobial activity of Co (II) metal chelates possibly because of the effect of the metal ion on the normal cell process. According to the Tweedy's chelation theory, chelation noticeably decreases the polarity of the metal ion due to partial sharing of its positive charge with donor groups and probable $\pi$-electron delocalization over the whole chelate ring. This chelation possibly will enhance the lipophilic nature of the central metal atom, which then favors its penetration through the lipid layers of cell membrane $[39,40]$. Further, these active Schiff base Co(II) metal complexes were examined to assess their minimum 
inhibitory concentration (MIC) (Table 5). According to the results, the Co (II) complexes were found to be active at lower concentrations than the existing antibiotics like Streptomycin but less than the Rifampicine and Itrazole.

Table 5. MIC values of the antimicrobial activity of Schiff base ligands, their Co (II) complexes and existing antibiotics

\begin{tabular}{|c|c|c|c|c|c|c|}
\hline Compound & $\begin{array}{c}\text { Escherichia } \\
\text { coli }\end{array}$ & $\begin{array}{c}\text { Klebsiella } \\
\text { pneumonia }\end{array}$ & $\begin{array}{l}\text { Basillus } \\
\text { subtilis }\end{array}$ & $\begin{array}{c}\text { Staphylococcus } \\
\text { aureus }\end{array}$ & $\begin{array}{l}\text { Aspergillus } \\
\text { flavus }\end{array}$ & $\begin{array}{l}\text { Fusarium } \\
\text { oxysporium }\end{array}$ \\
\hline$L_{1}$ & - & - & - & - & - & - \\
\hline $\mathbf{L}_{2}$ & - & 90 & - & - & 105 & - \\
\hline$L_{3}$ & 120 & - & - & 105 & 95 & 85 \\
\hline $\mathbf{L}_{4}$ & - & 95 & 85 & 90 & - & 90 \\
\hline$L_{5}$ & - & - & 80 & - & 95 & 80 \\
\hline$\left[\mathrm{Co}\left(\mathrm{L}_{1}\right)\left(\mathrm{H}_{2} \mathrm{O}\right)_{2}\right]$ & 35 & 30 & 30 & 30 & 35 & 40 \\
\hline$\left[\mathrm{Co}\left(\mathrm{L}_{2}\right)\left(\mathrm{H}_{2} \mathrm{O}\right)_{2}\right]$ & 55 & 50 & 45 & 55 & 60 & 55 \\
\hline [Co $\left.\left(\mathrm{L}_{3}\right) \mathrm{Cl}_{2}\right]$ & 55 & 50 & 55 & 60 & 45 & 60 \\
\hline$\left[\mathrm{Co}\left(\mathrm{L}_{4}\right) \mathrm{Cl}_{2}\right]$ & 45 & 45 & 40 & 75 & 55 & 50 \\
\hline$\left[\mathrm{Co}\left(\mathrm{L}_{5}\right)\left(\mathrm{H}_{2} \mathrm{O}\right)_{2}\right]$ & 80 & 80 & 85 & 80 & 55 & 75 \\
\hline Streptomycin ${ }^{a}$ & - & - & 02 & - & - & - \\
\hline Rifampicin $^{a}$ & 10 & 0.25 & 0.25 & 0.25 & - & - \\
\hline Itrazole $^{\mathrm{b}}$ & -- & - & - & - & 12 & 10 \\
\hline \multicolumn{7}{|c|}{${ }^{\mathrm{a} S t a n d a r d ~ f o r ~ a n t i b a c t e r i a l ~ s t u d i e s ~}$} \\
\hline \multicolumn{7}{|c|}{ bStandard for antifungal studies } \\
\hline
\end{tabular}

Among 5 Schiff base Co (II) complexes, two Schiff base ligands coordinate through two nitrogen atoms and two oxygen atoms, two Schiff base ligands coordinate through four nitrogen atoms and one Schiff base ligand coordinate through two nitrogen atoms and two sulfur atoms to a metal ion. On the basis of analytical and spectral data, distorted octahedral structures (Scheme 2) have been proposed for the Co (II) complexes. The Schiff base Co (II) complexes are found to be more efficient in antimicrobial studies than the uncoordinated Schiff bases.

\section{REFERENCES}

[1] Holm, R. H.; O'Connor, M. J. The stereochemistry of bis-chelate metal(II) complexes. Prog.Inorg. Chem. 1971, $14,241-401$.

[2] Oki, A. R.; Hodgson, D. J. Synthesis, characterization and catalytic properties of manganese(III) Schiff base complexes. Inorg. Chim. Acta. 1990, 170, 65-73.

[3] Singh, K.; Barwa, M. S.; Tyagi, P. Synthesis and characterization of cobalt(II), nickel(II), copper(II) and zinc(II) complexes with Schiff base derived from 4-amino-3-mercapto-6-methyl-5-oxo-1,2,4-triazine. Eur. J. Med. Chem. 2007, 42, 394-402.

[4] Singh, H. L.; Singh, J. B.; Sachedva, H. Synthesis, spectroscopic and antimicrobial Studies of lead (II) Complexes of Schiff Bases derived from amino acids and isatins. Spectroscopy Letters. 2013, 46, 286-296.

[5] Vigato, P.A.; Tamburini, S.; Bertolo, L. The development of compartmental macrocyclic Schiff bases and related polyamine derivatives. Coord. Chem. Rev. 2007,251, 1311-1492.

[6] El-Boraeya, H.A.; Abdel-Rahmanb, R.M.; Atiaa,Khalid, E.M.; Hilmya, H. Spectroscopic,thermal and toxicity studies of some 2-amino - 3- cyano - 1, 5 -diphenylpyrrole containing Schiff bases copper (II) complexes. Cent. Eur. J. Chem. 2010, 8, 820-833.

[7] Sohrab, E.; Loft-Ali, S.; Karim-nezhad, G.; Sahar, K. Electrochemical behavior of $\mathrm{N}_{2}$ SO Schiff-Base Co(II) complexes in non-aqueous media at the surface of solid electrodes. Int. J. Electrochem. Sci. 2009, 4, 846-854. 
[8] Priya, N. P.; Arunachalam, S.; Manimaran, A.; Muthupriya, D.; Jayabalakrishnan, C. Mononuclear Ru(III) Schiff base complexes: Synthesis, spectral, redox, catalytic and biological activity studies. Spectrochim. Acta Part A. 2009, 72, 670-676

[9] Seyedi, S.M.; Sandaroos ,R.; Zohuri, G. H.; Novel cobalt(II) complexes of amino acids-Schiff bases catalyzed aerobic oxidation of various alcohols to ketones and aldehyde. Chinese Chem.Letters, 2010, 21,1303-1306.

[10] Himeda, Y.; Komatsuzaki ,N.O.; Sugihara, H.; Arakawa, H.; Kasuga, K. Transfer hydrogenation of a variety of ketones catalyzed by rhodium complexes in aqueous solution and their application to asymmetric reduction using chiral Schiff base ligands. J. Mol. Cat. A. 2003, 195, 95-100.

[11] Reddy, V.; Patil, N.; Reddy, T.; Angadi, S. D. Synthesis, characterization and biological activities of Cu(II), Co(II), $\mathrm{Ni}(\mathrm{II}), \mathrm{Mn}$ (II) and $\mathrm{Fe}$ (III) complexes with Schiff base derived from 3-(4-chlorophenoxymethyl)-4-amino-5-mercapto1,2,4-triazole. E-Journal of Chemistry. 2008, 5, 529-538.

[12] Chakraborthy, H.; Paul, N.; Rahaman, M.L. Catalytical activities of Schiff bases aquo complexes of $\mathrm{Cu}(\mathrm{II})$ in the hydrolysis of amino acid esters. Trans.Met.Chem. 1994, 14, 524-526.

[13] Mohamed, G. G.; Omar, M.M.; Ibrahim, A. A. Biological activity studies on metal complexes of novel tridentate Schiff base ligand. Spectroscopic and thermal characterization. E. Journal . Medicinal. Chem. 2009, 44, 4801-4812.

[14] Raman, N.; Raja, S. J.; Sakthivel, A. Transition metal complexes with Schiff-base ligands 4-aminoantipyrine based derivatives. Jour.Coord .Chem. 2009, 62, 691-709.

[15] Hussain, N.; Joshi, P.; Bhandari, A.; Dangi, R.; Khanam, R.; Talesara, G.L. Synthesis, Biological Evaluation and Electrochemical Studies of $\mathrm{Cu}$ (II) and Ni (II) Complexes of N',N"-1,2-diphenylethane-1,2-diylidenedibenzohydrazide. International J. Pharm. Sci. Drug Res. 2010, 2, 272- 274.

[16] Abdalrazaq, E.A.; Ramadane, O. M. A .; Numa, K. S. A. Synthesis and Characterization of Dinuclear Metal Complexes Stabilized by Tetradentate Schiff Base Ligands. American J.App. Sciences. 2010, 7, 628-633.

[17] Geeta, B.; Shravankumar, K.; Reddy, P. M.; Ravikrishna, E.; Sarangapani, M.;.Reddy, K. K.; Ravinder.V. Binuclear cobalt(II), nickel(II), copper(II) and palladium(II) complexes of a new Schiff-base as ligand: Synthesis, structural characterization, and antibacterial activity. Spectrochim. Acta Part A. 2010, 77, 911-915.

[18] Holm, R.H.; Solomon, E.I. Preface: Biomimetic Inorganic Chemistry, Chem. Rev. 2004, 104, 347-348.

[19] Geeta, B.; Reddy, P. M.; Rani, K. S.; Hu, A.; Ravinder, V. Synthesis, Characterization and Biological Evaluation of Mononuclear $\mathrm{Co}(\mathrm{II}), \mathrm{Ni}(\mathrm{II}), \mathrm{Cu}(\mathrm{II})$ and $\mathrm{Pd}(\mathrm{II})$ Complexes with New N2O2 Schiff Base Ligands. Chem. Pharm. Bull. 2011, 59, 166-171.

[20] Reddy, P. M.; Prasad, A. V.S.S.; Rohini, R.; Ravinder, V. Catalytic reduction of pralidoxime in pharmaceuticals by macrocyclic Ni(II) compounds derived from orthophthalaldehyde. Spectrochim. Acta Part A. 2008, 70, 704-712.

[21] Shanker, K.; Rohini, R.; Ravinder, V.; Reddy, P. M.; Ho. Y.P. Ru(II) complexes of N4 and N2O2 macrocyclic Schiff base ligands: Their antibacterial and antifungal studies Spectrochim. Acta Part A. 2009, 73, 205-211.

[22] Reddy, P. M.; Prasad, A.V.S.S.; Shanker, K.; Ravinder, V. Synthesis, spectral studies and antibacterial activity of novel macrocyclic Co(II) compounds. Spectrochim. Acta Part A. 2007, 68, 1000-1006.

[23] Reddy, P. M.; Shanker, K.; Rohini, R.; Ravinder, V. Antibacterial active tetraaza macrocyclic complexes of Chromium (III) with their spectroscopic approach. Int. J. ChemTech. Res. 2009, 2, 367-372.

[24] Prasad, A. V. S. S.; Muralidhar Reddy, P.; Shanker, K.; Rohini , R.; Ravinder, V. Application of nickel-catalysed reduction and azo dye reactions for the determination of tinidazole. Color. Technol. 2009, 125, 284-287.

[25] Alam S. Synthesis, antibacterial and antifungal activity of some derivatives of 2-phenyl-chromen-4-one. Ind. Acad. Sci., J. Chem. Sci., 2004, 166(6), 325-331.

[26] Dzink, J. L.; Smith, C.; Socransky, S. S. Chemically defined medium for oral microorganisms. J. Clin. Microbio. 1984, 19(5), 599-605.

[27] Cushine, T. P. T.; Lamb A. J. Antimicrobial activity of flavonoids. Inter. J. Antimicrobial Agents, 2005, 26, 343-356.

[28] Okawa, H.; Nishio, J.; Ohoba, M.; Tadokoro, M.; Matumastsumoto, N.; Koikawa, M.; Kaida, S.; Fenton, D. E. Heterodinuclear copper(II)-lead(II) and copper(II)-M(II) (M = manganese, iron, cobalt, nickel, copper, zinc) complexes of macrocycles with dissimilar 4- and 5-coordination sites: synthesis, structures, and propertie. Inorg. Chem. 1993,32 ,2949-2957.

[29] Shakir, M.; Chishti ,H. T. N.; Chingsubam, P. Metal ion-directed synthesis of 16-membered tetraazamacrocyclic complexes and their physico - chemical studies Spectrochim. Acta. 2005, 64, 512-517.

[30] Shehab A. Sallam. Binuclear Copper(II), Nickel(II) and Cobalt(II) Complexes with N2O2 Chromophores of Glycylglycine Schiff-Bases of Acetylacetone, Benzoylacetone and Thenoyltrifluoroacetone. Tran. Met. Chem. 2006, 31, 46-55. 
[31] Shakir, M.; Nasman, O. S. M.; Varkey ,S. P. Binuclear n-6 22-membered macrocyclic transition metal complexes synthesis and characterization, Polyhedron, 1996, 15, 309-314.

[32] Yang, H.; Sun, W. H.; Li, Z.; Wang, L. Solvent-free syntheses of salicylaldimines assisted by microwave irradiation Syn. Comm. 2002, 32, 2395-2402.

[33] Jeewoth, T.; Bhowan, M. G.; Wah H. L. K. Synthesis, characterization and antibacterial properties of Schiff bases and Schiff base metal complexes derived from 2,3-diaminopyridine. Transition Met. Chem. 1999, 24, 445-448.

[34] Chohan Z. H.; Praveen, M. Synthesis, characterization, coordination and antibacterialproperties of novel asymmetric 1,1'-disubstituted ferrocene-derived Schiff-base ligands and their $\mathrm{Co}(\mathrm{II}), \mathrm{Cu}(\mathrm{II}) \mathrm{Ni}(\mathrm{II})$ and $\mathrm{Zn}(\mathrm{II})$ complexes. Appl. Organomet. Chem. 2001, 15, 617-625.

[35] Colak, A.T.; Tumer, M.; Serin, S. Nickel ion as a template in the synthesis of macrocyclic imine-oxime complexes from carbonyl compounds and o-phenylenediamine. Transition Met. Chem. 2000, 25, 200-204.

[36] Vinod, K.; Rajesh, D. Synthesis and Studies of Some metal chelates with Phenylglyoxal 4-iminoantipyrine (PGIA) and 4-N-(m-phenoxybenzylidene)aminoantipyrine [4-N-(MPB)AAP]. J. Ind. Coun. Chem. 2003, 20(1), 61-68.

[37] Geary, W. J. The use of conductivity measurements in organic solvents for the characterization of coordination compounds. Coord. Chem. Rev. 1971, 7, 81-115.

[38] Allan, J. R.; Veitch, P. M. The preparation, characterization and thermal analysis studies on Complexes of cobalt (II) with 2-, 3-, 4-cyanopyridines. J. Thermal Anal. 1983, 27, 3-15.

[39] Tweedy, B.G. Plant extracts with metal ions as potential antimicrobial agents. Phytopathology. 1964, 55, $910-914$.

[40] Atabay, N. M. A.; Dulger, B.; Gucin, F. Structural characterization and antimicrobial activity of 1,3-bis(2benzimidazyl)-2-thiapropane ligand and its $\mathrm{Pd}(\mathrm{II})$ and $\mathrm{Zn}(\mathrm{II})$ halide complexes. Eur. J. Med. Chem. 2005, 40, 10961102. 